\title{
The effect of macroeconomic variables on the poverty rate in Indonesia
}

\author{
Rifda Nabila ${ }^{1, *}$ \\ ${ }^{1}$ Faculty of Islamic Economics and Business, IAIN Salatiga, Indonesia \\ *) Corresponding Author (e-mail: rifdanabila@iainsalatiga.ac.id)
}

\begin{abstract}
Poverty is one of the main issues that is widely discussed in developing countries, including Indonesia. In addition, poverty is a benchmark for socio-economic conditions in assessing the success of development carried out by the state. This study aims to determine the relationship between Gross Regional Domestic Product (GRDP), Human Development Index $(\mathrm{HDI})$, and unemployment on poverty in Indonesia. The data used are cross-sectional data from 34 provinces during 2020. The analysis used is a multiple linear regression approach. The results of the study found that the Human Development Index (HDI) had a negative effect on poverty. Meanwhile, Gross Regional Domestic Product (GDP) and unemployment have no effect on poverty. The novelty of this research is to confirm and confirm several research results related to the factors that influence poverty in Indonesia.
\end{abstract}

Keywords: Poverty, GDRP, HDI, Unemployment

\begin{abstract}
Abstrak
Kemiskinan merupakan salah satu isu utama yang banyak dibicarakan di negara-negara berkembang, termasuk Indonesia. Selain itu, kemiskinan merupakan tolok ukur kondisi sosial ekonomi dalam menilai keberhasilan pembangunan yang dilakukan negara. Penelitian ini bertujuan untuk mengetahui hubungan antara Produk Domestik Regional Bruto (PDRB), Indeks Pembang unan Manusia (IPM), dan pengangguran terhadap kemiskinan di Indonesia. Data yang digunakan merupakan data cross section yang berasal dari 34 Provinsi selama tahun 2020. Analisis yang digunakan menggunakan pendekatan regresi linear berganda. Hasil penelitian menemukan bahwa Indeks Pembangunan Manusia (IPM) berpengaruh negatif terhadap kemiskinan. Sedangkan Produk Domestik Regional Bruto (PDRB) dan pengangguran tidak berpengaruh terhadap kemiskinan. Kebaharuan dalam penelitian ini adalah untuk mengkonfirmasi dan mengkonfortir beberapa hasil penelitian terkait faktorfaktor yan g mempen garuhi kemiskinan di Indonesia.

Kata kunci: Kemiskinan, PDRB, IPM, Pengangguran

How to cite: Rifda Nabila. The effect of macroeconomic variables on the poverty rate in Indonesia. Journal of Economics Research and Policy Studies, 1-9. https://d oi.org/10.53088/jerps.v1i2.87
\end{abstract}

\section{Introduction}

Development is a process of change towards a better and continuous direction to achieve the goal of realizing an Indonesian society that is just, competitive, advanced, and prosperous within the unitary state of the Republic of Indonesia. Development must be directed in such a way that each stage is getting closer to the goal. The big problem in development faced by many developing countries including 
Indonesia is poverty or the number of people below the poverty line (Alhudhori, 2017). Poverty is a condition in which a person or family is unable to meet primary needs. Indonesia is a country full of paradoxes. This country is fertile and has abundant natural resources, but quite a lot of people who are classified as poor. In essence, economic development is a series of activities by utilizing all potential as effective and efficient basic capital through design in order to improve the welfare of the community. Development is aimed at increasing people's income which cannot be separated from the success of economic development and is measured in the level of economic growth in an area (Amir, 2007).

It is undeniable that poverty is a problem that has not been completely solved so far. Various causes of poverty have been formulated from certain human traits that are unwilling or unable to try to the existence of structural efforts that are intentional. There are several programs that are trying to overcome poverty but have not shown results or even increased poverty levels (Indro, 2013).

One of the causes of poverty is the lack of income and assets (lack of income and assets) to meet basic needs such as food, clothing, shelter and an acceptable level of health and education (World Bank Institute, 2004). In addition, poverty is also related to limited em ployment opportunities and usually those who are categorized as poor (the poor) do not have a job (unemployment), and their education and health levels are generally inadequate. Addressing the problem of poverty cannot be done separately from the problems of unemployment, education, health and other problems that are explicitly related to the problem of poverty. In other words, the approach must be carried out across sectors, across actors in an integrated and coordinated and integrated manner (Susanti, 2013).

Economic growth is the key to reducing poverty in a region. With increasing economic growth in each province, it indicates that the government is able to improve the welfare of its people, thereby reducing poverty levels. GRDP is one indicator of a region's economic growth. GRDP is the net value of final goods and services produced by various economic activities in an area within a period (Sasana, 2006). The higher the GRDP of an area, the greater the potential source of regional revenue.

The quality of human resources can also be a factor causing the occurrence of poor people. The quality of human resources can be seen from the quality of life index/human development index. In the context of economic development in a region, the Human Development Index (HDI) is determined as one of the main measures included in the basic pattern of regional development. This indicates that HDI occupies an important position in regional development management. The HDI function and other human development indicators will be the key to the implementation of targeted planning and development. HDI which is a benchmark for the development of a region should have a positive correlation with the low Human Development Index (HDI) which will result in low work productivity of the population. Low productivity results in low income. So that the low income causes a high number of poor people (Sayifullah \& Gandasari, 2016). 
Another factor that also influences the level of poverty is unemployment. Because unemployment is a population problem that is closely related to poverty. Unemployment can be caused by the addition of a new workforce that occurs every year, while employment does not increase. In addition, there are industries that are bankrupt, so they have to lay off their workers. Employment problems are problems that are so real and close to the community. In fact, em ployment problems can cause new problem s in the economic and non-economic fields.

One of the elements that determine the prosperity of a society is the level of income. Community income reaches its maximum if the condition of full employment can be realized. According to Sukirno (2014), unemployment will have the effect of reducing people's income, and it will reduce the level of prosperity that has been achieved. The lower the level of prosperity will cause another problem, namely poverty.

\section{Literature Review}

\section{Poverty}

Poverty has been recognized as a multidimensional phenomenon. This means that poverty cannot only be understood as a lack or incapacity economically (Retnowati \& Harsuti, 2017). Haughton \& Khandker (2009) express thoughts about poverty with a broader approach, namely that poverty arises when people do not have the main abilities, have no income, do not get adequate education, have poor health conditions, feel insecure, have confidence low self-esteem or a feeling of powerlessness or lack of rights such as free speech.

The concept of poverty has been accepted as a multidimensional phenomenon by various disciplines and has even been included in the development agenda, its multidimensional measurement and application is still limited (Cecchetti et al., 2011). The measurement of poverty that has been carried out so far is mostly focused on measuring poverty in terms of income or expenditure.

\section{Gross Regional Domestic Product}

Gross Regional Domestic Product (GRDP) is the amount of added value generated for all business and service areas in a region, applying the total value of final goods and services produced by all economic units. GRDP itself can be interpreted as the amount of added value produced by all business units or is the total value of goods and services by all economic units in a region.

According to Todaro (2006) GRDP is the total value of all final outputs produced by an economy at the regional level (whether that is done by local residents or residents from other areas who live in the area). The higher the GRDP value of an area, this indicates a high level of economic growth and illustrates that the area is progressing in the economy. In essence, the economic growth of a region can occur when endogenous (factors from within the region) and exogenous (factors from 
outside the region) are concerned and combine. The approach commonly used in explaining regional growth is to use macroeconomic models

\section{Human Development Index}

The human development index explains how the population can access development outcomes in obtaining income, health, education, and so on (Mahroji \& Nurkhasanah, 2019). This index was introduced by the United Nations Development Program (UNDP) n 1990 and is published regularly in the annual Human Development Report (HDR).

HDI consists of 3 (three) components that affect the success rate of human development, namely:

- Health Component, In the human development index, this health component is reflected in people's life expectancy, which is the estimated average number of years that a person can take during his life. There are two types of data used in calculating the Life Expectancy Rate, namely Children Born Alive (ALH) and Children Still Living (AMH). Meanwhile, to calculate the life expectancy index, the maximum value of life expectancy is used according to UNDP standards, where the highest number as the upper limit for calculating the index is used for 85 years and the lowest is 25 years.

- Education Component, In the human development index, the education component is represented by the Literacy Rate (AMH) and the Average Years of Schooling. Literacy Rate is the ratio between the population aged 15 years and over who can read and write with the population aged 15 years and over. The maximum limit for the literacy rate is 100 while the minimum limit is 0 (UNDP standard). This describes the condition of 100 percent or all people are able to read and write, and a value of zero reflects the opposite condition. Meanwhile, the average length of schooling is the average number of years spent by residents aged 15 years and over to take all types of formal education that have been undertaken. The maximum limit for the average length of schooling is 15 years and the minimum limit is 0 years (UNDP standard).

- Purchasing Power Component, In the human development index the purchasing power component is represented by Adjusted Real Per capita Income. Income parameters with indicators of people's purchasing power, measuring people who are independent and have access to decent.

\section{Unemployment}

Unem ployment is the inability of the workforce to obtain jobs as needed or desired (Kalsum, 2017). Meanwhile, according to Badan Pusat Statistik (2021) n em ployment indicators, unem ployment is a population who does not work but is looking for work or is preparing a new business or residents who are not looking for work because they have been accepted to work but have not started work.

According to Murni (2016) unemployment is a person who does not have a job or has no income. Meanwhile, Sukirno (2014) explains that unemployment is a 
condition in which a person belonging to the labor force wants to get a job but has not been able to get it. So it can be concluded that unemployment is a condition in which a person who is classified as a labor force has not got a job and is trying to find work.

\section{Research Method}

This type of research was conducted with a descriptive method. Descriptive research is a research method carried out to make a picture or describe a situation objectively. The data used is secondary data. In the form of cross section data from 34 provinces in Indonesia. Secondary data collected includes data on poverty, regional gross domestic product, human developmentindex and unem ployment.

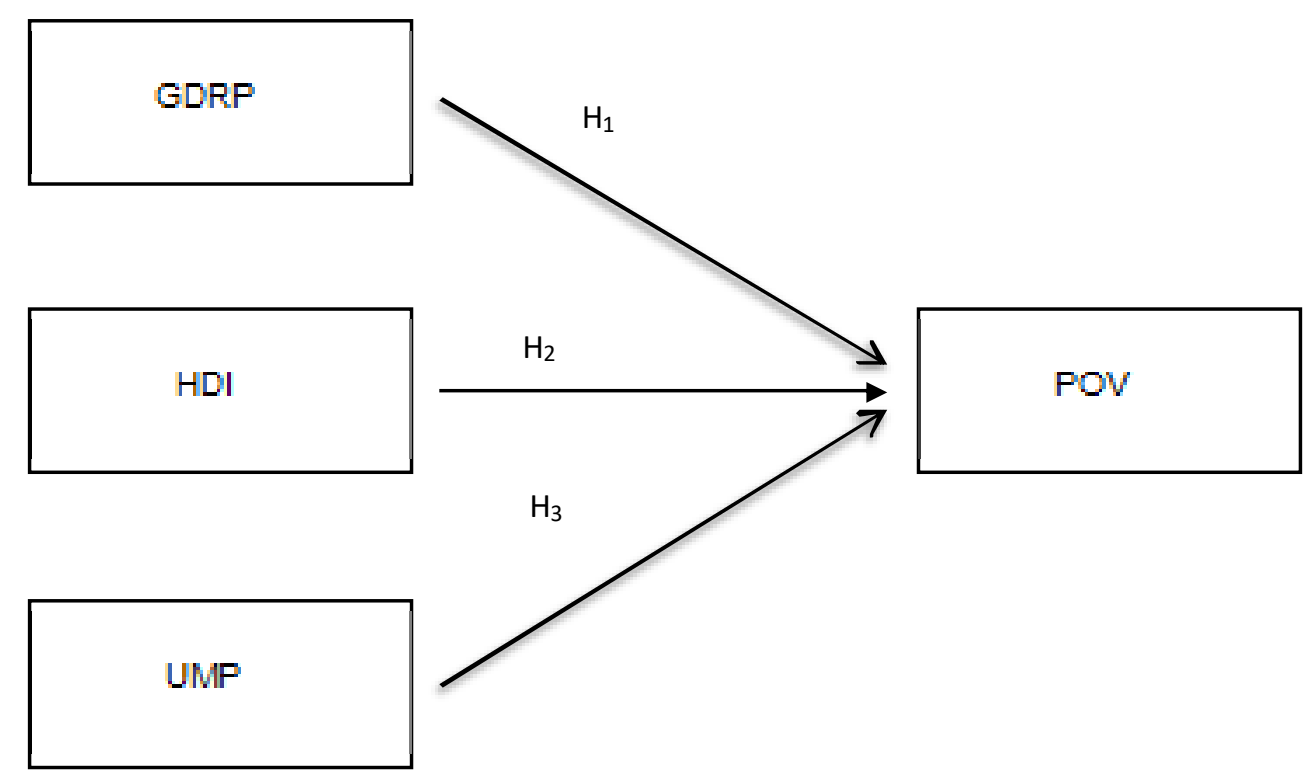

Figure 1. Researc framework

$\mathrm{H}_{1}$ : Gross Regional Domestic Product affects poverty

$\mathrm{H}_{2}$ : Human developmentindex affects poverty

$\mathrm{H}_{3}$ : Unemployment affects poverty

This study uses a multiple regression model with the following regression equation

Note:

$$
P O V=\alpha+\beta_{1} G D R P+\beta_{2} H D I+\beta_{3} U M P+e
$$

$$
\begin{array}{ll}
\text { POV } & \text { : Poverty } \\
\text { GRDP } & \text { : Gross Regional Domestic Product } \\
\text { HDI } & \text { : Human Development Index } \\
\text { UMP } & \text { : Unemployment } \\
\alpha & \text { : Intersept or constant } \\
\beta & \text { : coefficientor slope } \\
\text { e } & \text { : error term }
\end{array}
$$


Data on Poverty (POV), Gross Regional Domestic Product (GDRP), Human Development Index (HDI), Unemployment (UMP) were taken from data from the Central Statistics Agency (BPS)

\section{Results and Discussion}

\subsection{Results}

The estimation results of this research model can be seen in table 1 below:

Table 1. Research Model Estimation Results

\begin{tabular}{crrrc}
\hline \multicolumn{1}{c}{ Variable } & Coefficient & Std. Error & t-Statistic & Prob. \\
\hline C & 69.30577 & 15.89183 & 4.361094 & 0.0001 \\
GRDP & 0.243633 & 0.364543 & 0.668325 & 0.5090 \\
HDI & -0.814009 & 0.237555 & -3.426610 & 0.0018 \\
UMP & -0.055465 & 0.428115 & -0.129556 & 0.8978 \\
\hline R-squared & 0.430751 & & & \\
Adjusted R-squared & 0.373827 & & & \\
F-statistic & 7.567017 & & & \\
Prob(F-statistic) & 0.000653 & & \\
\hline
\end{tabular}

Based on the estimation results in table 2, the empirical model obtained in this study is as follows

$$
P O V=69.30577+0.243633 G D R P-0.814009 H D I-0.055465 U M P
$$

Based on the output in table 1, it can be seen that GRDP has no effect on poverty because the probability value is $0.5090>0.05$. This means that if GRDP increases, it will not have a significant impact on increasing the number of poor people in Indonesia.

Furthermore, the HDI variable has a negative effect on the level of poverty with a coefficient value of -0.814009 and a significant $0.0018<0.05$. This shows that, if the $\mathrm{HDI}$ value increases by $1 \%$, the poverty rate will decrease by $0.81 \%$, assuming other variables are held constant.

The relationship between unemployment and poverty shows that unemployment has no effect on poverty because the probability value is $0.8978>0.05$. This means that if unemployment increases, it will not have a significant impact on reducing the number of poor people in Indonesia

\subsection{Discussion}

It can be seen that HDI has a relationship with poverty, with a negative coefficient. This means that when the quality of human resources increases, poverty will decrease. Vice versa. The reduced poverty rate due to an increased HDI indicates that the HDI can increase human labor productivity, which will increase income to meet the needs of a decent life. This study supports previous research, namely research by Prasetyoningrum \& Sukmawati (2018) and Sofilda et al (2014), which 
show that HDI has a negative and significant effect on poverty levels in the districts/cities of Papua Province.

HDI consists of 3 dimensions, namely health, education, and decent living per capita income, which greatly determines human quality. Education plays an important role in increasing the ability to absorb modem technology and develop the capacity to realize growth and development. In addition, health is a requirement in increasing productivity, because with health, education is easy to achieve. In this regard, health and education are important components of economic development in helping to reduce poverty. With education and health, high income will be easy to get. On the other hand, with high income, it will be easy to spend money on health and education.

The government always strives to continuously improve the HDI to build the quality of human life in fighting poverty. By paying attention to the three dimensions that make up the HDI, this study states that the HDI value tends to reduce the level of poverty in Indonesia.

In this study, the relationship between GDRP and poverty shows that these two variables have no effect. The results of this study are in accordance with the results of the research by Prasetyoningrum \& Sukmawati (2018) which shows that the GDRP does not have a significant effect on poverty. This is because the distribution of development results is not evenly distributed to all regions in Indonesia so that a high economy is only enjoyed by a few people or certain regions. High economic growth does not provide benefits to the poor, and this growth is also not generated by many people.

The same correlation results also occur for the variables of unemployment and poverty. These results are in line with research conducted by Sayifullah \& Gandasari (2016) that the unemployment variable shows insignificant results on the poverty variable. Like the population included in the open unemployment group, there are several types of unemployed, namely those who are looking for work, those who are preparing for a business, those who are not looking for work because they feel it is impossible to get a job and finally those who already have a job but have not started working. Among the four categories of open unem ployment above, some of them are in the informal sector, and some have jobs with working hours of less than 35 hours a week. Besides that, there must also be those who are trying or preparing their own business, there are also those who are waiting to start working, there are also those who have part-time jobs (part time) but with incomes exceeding those of normal working people, and all of these groups fall into the open unem ployment category.

\section{Conclusion}

The findings of this study indicate that the human development index has a negative effect on poverty in Indonesia. On the other hand, the level of GRDP and unemployment do not have a significant effect on poverty in Indonesia. Based on these findings, in an effort to alleviate poverty in Indonesia, the govemment is 
advised to improve programs that are able to improve the quality of Indonesian Human Resources.

\section{Acknowledgements}

We are very grateful to those who have helped in the completion of this research. The author also appreciates the efforts of the editors and the critical comments provided by anonymous reviewers.

\section{References}

Alhudhori, M. (2017). Pengaruh IPM, PDRB Dan Jumlah Pengangguran terhadap Penduduk Miskin Di Provinsi Jambi. EKONOMIS: Journal of Economics and Business, 1(1), 113. https://doi.org/10.33087/ekonomis.v1i1.12

Amir, A. (2007). Pengaruh inflasi dan pertumbuhan ekonomi terhadap pengangguran di Indonesia. Jurnal Inflasi Dan Pengangguran, 1(1), 4-9.

Badan Pusat Statistik. (2021). Konsep/Penjelasan Teknis. Badan Pusat Statistik. https://www.bps.go.id/subject/6/tenaga-kerja.htm|\#subjekViewTab1

Cecchetti, S., Mohanty, M., \& Zampolli, F. (2011). The Real Effects of Debt. BIS Working Paper, 352.

Haughton, J., \& Khandker, S. R. (2009). Handbook on poverty+ inequality. World Bank Publications.

Indro, P. (2013). Kemiskinan Global Dalam Prespektif "Development as Freedom" Amartya Sen Kasus: Indonesia. Jurnal IImiah Hubungan Internasional UNPAR, 9(1), 98363. https://doi.org/10.26593/jihi.v9i1.538.

Kalsum, U. (2017). Pengaruh Pengangguran Dan Inflasi Terhadap Pertumbuhan Ekonomi Di Sumatera Utara. EKONOMIKAWAN: Jurnal IImu Ekonomi Dan Studi Pembangunan, $17(1)$, 87-94. https://doi.org/10.30596/ekonomikawan.v17i1.1183

Mahroji, D., \& Nurkhasanah, I. (2019). Pengaruh Indeks Pembangunan Manusia Terhadap Tingkat Pengangguran Di Provinsi Banten. Jurnal Ekonomi-Qu, 9(1). https://doi.org/10.35448/jequ.v9i1.5436

Murni, A. (2016). Ekonomika makro.

Prasetyoningrum, A. K., \& Sukmawati, U. S. (2018). Analisis Pengaruh Indeks Pembangunan Manusia (Ipm), Pertumbuhan Ekonomi, Dan Pengangguran Terhadap Kemiskinan Di Indonesia. Equilibrium: Jurnal Ekonomi Syariah, 6(2), 217. https://doi.org/10.21043/equilibrium.v6i2.3663

Retnowati, D., \& Harsuti. (2017). Pengaruh Pengangguran terhadap Tingkat Keiskinan di Jawa Tengah. Sustainable Competitive Advantage (SCA), 6(1), 608-618.

Sasana, H. (2006). Analisis dampak desentralisasi fiskal terhadap pertumbuhan ekonomi di kabupaten/kota provinsi Jawa Tengah. Jurnal Dinamika Pembangunan (JDP), 3(Nomor 2), 146-170.

Sayifullah, S., \& Gandasari, T. R. (2016). Pengaruh Indeks Pembangunan Manusia Dan Pengangguran Terhadap Kemiskinan Di Provinsi Banten. Jurnal Ekonomi- 
Qu, 6(2), 236-255. https://doi.org/10.35448/jequ.v6i2.4345

Sofilda, E., Hamzah, M., \& Sholeh, A. (2014). Human Development and Poverty in Papua Province (An Analysis of Simultaneous Approach on Panel Data Regression). OIDA International Joumal of Sustainable Development, 06(06), $51-62$.

Sukirno, S. (2014). Makroekonomi teori pengantar. Jakarta: PT Raja Grafindo Perkasa.

Susanti, S. (2013). Pengaruh Produk Domestik Regional Bruto, Pengangguran dan Indeks Pembangunan Manusia terhadap Kemiskinan di Jawa Barat dengan Menggunakan Analisis Data Panel. Jurnal Matematika Integratif, 9(1), 1. https://doi.org/10.24198/jmi.v9i1.9374

Todaro, M. P. (2006). stephen C. Smith. Economic Development, 10.

World Bank Institute. (2004). Dasar-Dasar Analisis Kemiskinan. 